\title{
Surface ozone trend details and interpretations in Beijing, 2001-2006
}

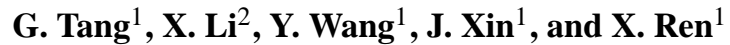 \\ ${ }^{1}$ State Key Laboratory of Atmospheric Boundary Layer Physics and Atmospheric Chemistry (LAPC), Institute of \\ Atmospheric Physics, Chinese Academy of Sciences, Beijing 100029, China \\ ${ }^{2}$ Beijing Municipal Environmental Protection Bureau, Beijing 100044, China
}

Received: 12 March 2009 - Published in Atmos. Chem. Phys. Discuss.: 27 March 2009

Revised: 11 November 2009 - Accepted: 12 November 2009 - Published: 20 November 2009

\begin{abstract}
Beijing is a megacity situated in the rapidly developing Beijing-Tianjin-Hebei region of northern China. In this study, we analyze data on ozone and nitrogen oxide levels obtained at six urban sites in Beijing between the months of July and September. Our goal is to investigate average trends and interpretations over the 2001-2006 period. Average concentrations of $\mathrm{NO}_{\mathrm{x}}\left(\mathrm{NO}_{\mathrm{x}}=\mathrm{NO}+\mathrm{NO}_{2}\right), \mathrm{O}_{3}$, and $\mathrm{O}_{\mathrm{x}}\left(\mathrm{O}_{\mathrm{x}}=\mathrm{O}_{3}+\mathrm{NO}_{2}\right)$ were $49.2 \pm 5.9 \mathrm{ppbv}, 26.6 \pm 2.8 \mathrm{ppbv}$, and $60.3 \pm 1.9$ ppbv, respectively. $\mathrm{NO}_{\mathrm{x}}$ concentrations decreased linearly at a rate of $3.9 \pm 0.5 \mathrm{ppbv} / \mathrm{yr}$ after 2002 , while ozone concentrations increased at a rate of $1.1 \pm 0.5 \mathrm{ppbv} / \mathrm{yr}$ during 2001-2006, and $\mathrm{O}_{\mathrm{x}}$ concentrations remained nearly constant. The reduction of $\mathrm{NO}_{\mathrm{x}}$ emissions and elevated non-methane hydrocarbon (NMHCs) emissions may have contributed to the increased $\mathrm{O}_{3}$ concentrations in Beijing. When the contributions from Beijing's urban and surrounding areas were disaggregated via trajectory cluster analysis, daily maximum and average $\mathrm{O}_{\mathrm{x}}$ concentrations attributable to Beijing's local emissions increased linearly at rates of $1.3 \pm 0.6 \mathrm{ppbv} / \mathrm{yr}$ and $0.8 \pm 0.6 \mathrm{ppbv} / \mathrm{yr}$, while the $\mathrm{O}_{\mathrm{x}}$ concentrations attributable to regional areas decreased linearly at rates of $0.6 \pm 0.3 \mathrm{ppbv} / \mathrm{yr}$ and $0.5 \pm 0.3 \mathrm{ppbv} / \mathrm{yr}$, respectively. The decrease in $\mathrm{O}_{\mathrm{x}}$ concentrations of the surrounding areas was found to counteract increasing Beijing urban $\mathrm{O}_{\mathrm{x}}$ production, leading to nearly constant $\mathrm{O}_{\mathrm{x}}$ concentrations in the Beijing region over the study period. Our results may be helpful for redefining government strategies to control the photochemical formation of air pollutants in the Beijing region. Our conclusions have relevance for developing megacities worldwide.
\end{abstract}

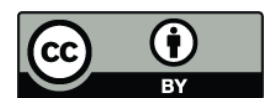

Correspondence to: Y. Wang

(wys@dq.cern.ac.cn)

\section{Introduction}

Ozone is produced naturally both in the Earth's upper atmosphere and at ground level. Tropospheric ozone is both a greenhouse gas (Houghton et al., 2001) and an important source of global $\mathrm{O}_{3}$ (Akimoto, 2003). Aside from these global effects, emissions of anthropogenic ozone precursors from urban and industrialized areas can elevate ozone concentrations in downwind suburban and rural areas (NRC, 1991). In addition, photochemical ozone is a key determinant of the atmospheric oxidation state and a major constituent of photochemical smog, which impacts local air quality (Finlayson-Pitts and Pitts, 2000). The production of elevated levels of $\mathrm{O}_{3}$ at ground level is of particular concern because ozone is known to have adverse effects on human health, vegetation, and a variety of materials (NRC, 1991; POPG, 1997). Along with accelerated urbanization, increases in surface ozone concentrations have been observed in areas throughout China (Xiaoyan et al., 1989; Xiaoyan et al., 1995; Zhang et al., 1998; Ma et al., 2000; Xu et al., 2008). Understanding the determinants of tropospheric $\mathrm{O}_{3}$ formation in Beijing may help us better understand and forecast air quality in Chinese cities and around the globe.

Beijing has a population of 16 million within an area of $16800 \mathrm{~km}^{2}$, making it one of the largest and most densely populated cities in Northern China. Coal emissions and photochemical smog pollution have become increasingly serious with the rapid growth of Beijing's industrial sector since the 1980s. Zhang et al. (1998) began measuring $\mathrm{O}_{3}$ concentrations at a single site in Beijing in 1982. The resulting time series reveals a marked increase in photooxidant concentrations over the 1982-1998 period. Since 1998, pollution from the burning of coal has been reduced substantially

Published by Copernicus Publications on behalf of the European Geosciences Union. 


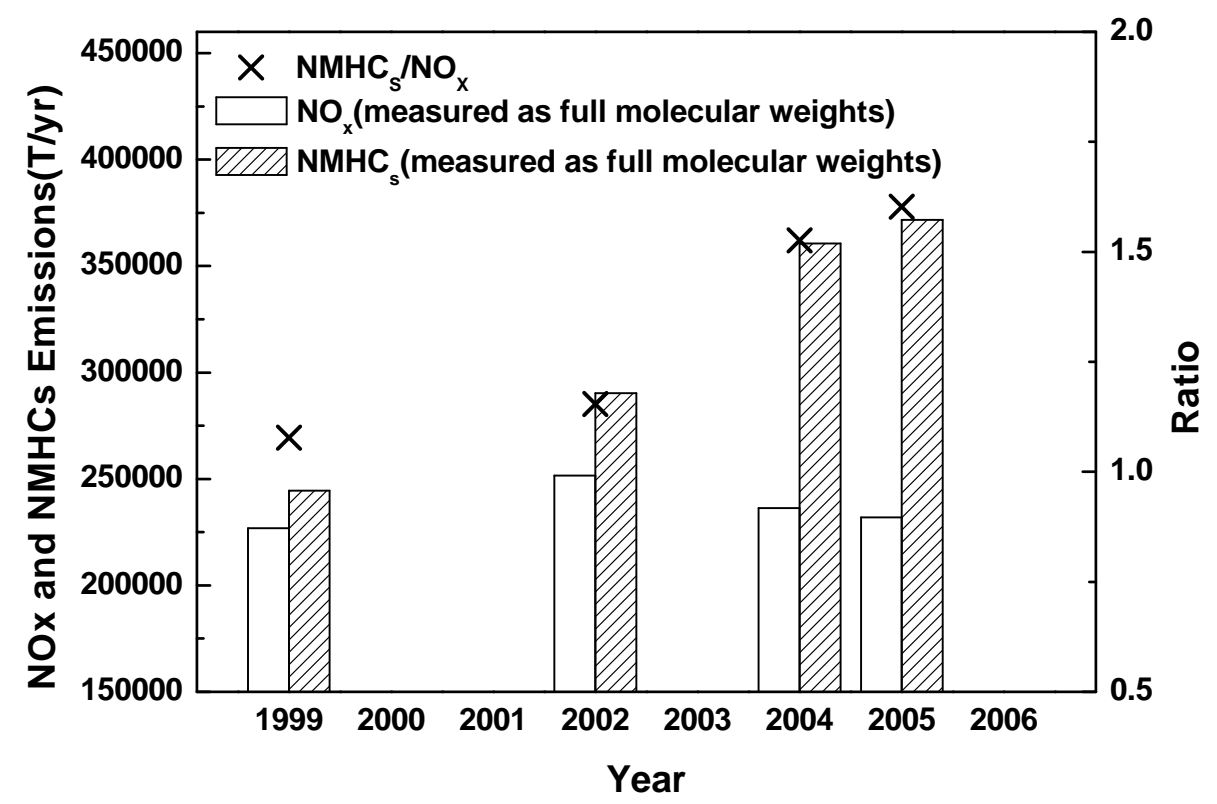

Fig. 1. $\mathrm{NO}_{\mathrm{x}}$ and NMHCs emissions and the ratio of NMHCs to $\mathrm{NO}_{\mathrm{x}}$ in Beijing, 2001-2006. (National Science and Technology Department of Rural and Social Development Division, 2002; Beijing Municipal Environmental Protection Bureau, 2007; Beijing Municipal Environmental Protection Bureau, 2006; Tsinghua University, 2007).

(Zhang et al., 2006). However, skyrocketing land prices in the downtown area, accompanied by accelerated construction of commercial developments, have led to substantial urban sprawl and the migration of residential neighborhoods to peripheral districts. Changes in urban structure and in residents' lifestyles have increased the number of automobiles in the Beijing region (Beijing Municipal Bureau of Statistics, 2008). Photochemical air pollution from domestic sources has become increasingly problematic. Since Beijing's successful bid in 2001 to host the Olympic Games, the local government has gradually tightened the regulations that govern emissions from automobiles and from non-vehicular sources in the city. These changing regulations have produced rapid shifts in the spatial and temporal distributions of $\mathrm{NO}_{\mathrm{x}}$ and NMHCs emissions (total amount of emissions) in the city (Fig. 1). This situation offers us a meaningful context to investigate the relationships between $\mathrm{O}_{3}$ and its precursors in an urban environment.

In this study, we illustrate the annual trends in atmospheric concentrations of $\mathrm{O}_{3}$ and related components in Beijing's urban areas during the period from July 2001 until September 2006. A combined approach incorporating emissions inventories, meteorological data, and trajectory cluster analysis is used to evaluate factors influencing $\mathrm{O}_{3}$ and $\mathrm{O}_{x}$ concentrations in Beijing and to identify strategies for controlling photochemical pollution in that city.

\section{Methods}

\subsection{Data sources}

Air quality data were collected at six sites (A1-A6) in downtown Beijing (Fig. 2). These sites are part of the Air Quality Monitoring Network established by the Institute of Atmospheric Physics (IAP). In order to focus on those months of relevance to the Olympic Games, ambient concentrations were recorded hourly throughout July, August, and September. In some cases, data were discarded due to equipment malfunctions, system failures, and power interruptions.

Surface ozone concentrations were measured using a Model 49 or 49C ozone analyzer from Thermo Environmental Instruments (TEI), Inc. $\mathrm{NO}_{\mathrm{x}}$ levels were measured using TEI Model $42 \mathrm{C}$ and $42 \mathrm{CTL} \mathrm{NO}$ and $\mathrm{NO}_{2}$ analyzers. The TEI Model 49 detector was found to exhibit a detection limit of $2 \mathrm{ppbv}$ and a precision of $2 \mathrm{ppbv}$, while Model 49C had a detection limit of $1 \mathrm{ppbv}$ and a precision of $1 \mathrm{ppbv}$. Both $\mathrm{NO}_{\mathrm{x}}$ analyzers had a precision of $0.4 \mathrm{ppbv}$, with detection limits for Model 42C and 42CTL of 0.4 ppbv and 0.05 ppbv, respectively.

Data quality was evaluated and certified by the China National Accreditation Board of Laboratories (CNAL) and is consistent with international requirements. IAP personnel strictly adhered to national environmental monitoring standards. Quality control checks, including automatic zerocalibration and span checks of gas analyzers, were performed daily, and manual calibrations with standard gases were conducted weekly. The $\mathrm{NO}_{\mathrm{x}}$ analyzers have been 


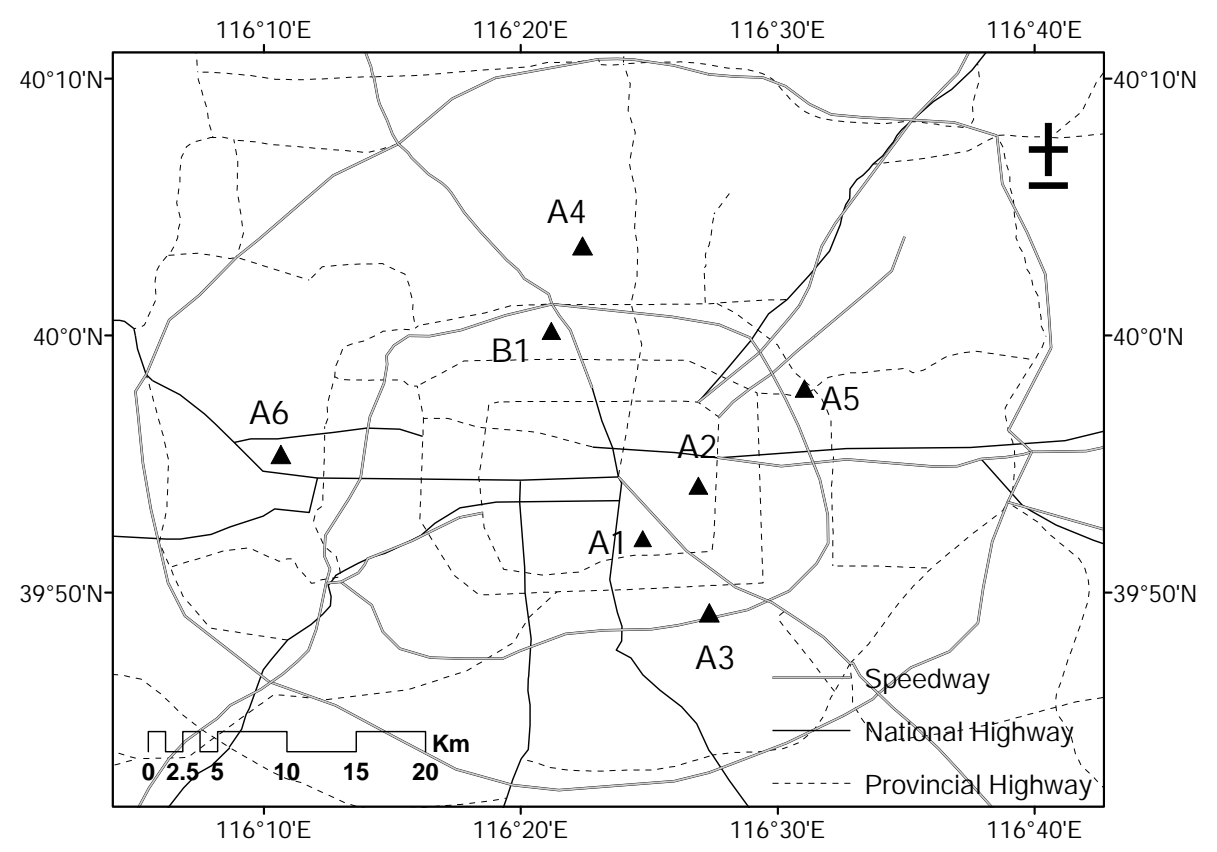

Fig. 2. Monitoring sites in Beijing, 2001-2006.

zero-checked and span-checked using a zero gas generator (TEI Model 111) and an internal ozone source of a multigas calibrator (TEI Model 146C) with NO standard (National Centre for Standard Materials, Beijing, China). Multi-point calibrations of the ozone analyzer used an ozone calibrator (TEI Model 49CPS). Sampling methods and instrument protocols, as well as quality assurance/quality control (QA/QC) procedures for air quality monitoring, are described in detail in the Chinese National Environmental Protection Standard, Automated Methods for Ambient Air Quality Monitoring (HJ/T193-2005; State Environmental Protection Administration of China, 2006).

Meteorological variables, including temperature and precipitation, were collected at the B1 site at an altitude of $8 \mathrm{~m}$ above ground level (AGL) in downtown Beijing during 2001-2006.

\subsection{Total oxidant concentrations}

We present a simplified scheme that describes photochemical reactions for $\mathrm{O}_{3}$ and its precursors in Fig. 3. Atmospheric ozone at ground level is formed in the presence of UV light $(\lambda<424 \mathrm{~nm})$ through the direct photolysis of nitrogen dioxide. Nitrogen dioxide, in turn, is formed by the oxidation of nitric oxide, a species typically emitted from fossil fuel combustion (Seinfeld and Pandis, 1998). Two major pathways are known for $\mathrm{NO}_{2}$ formation in urban atmospheres: $\mathrm{NO}$ oxidation either by $\mathrm{O}_{3}$ or by peroxyl radicals produced by the photooxidation of non-methane hydrocarbons (Atkinson, 2000). In terms of the ozone pathway, it is clear that the $\mathrm{O}_{3}$ production cycle (Fig. $3 b$ ) generates $\mathrm{O}_{3}$, whereas the photo-stationary reactions (Fig. 3a) comprise a "do nothing cycle". In urban areas where $\mathrm{O}_{3}$ precursors are present at sufficiently high concentrations, the radical pathway has been assumed to dominate, especially during summer months. However, the $\mathrm{O}_{3}$ pathway remains important in areas that are associated with high $\mathrm{NO}_{\mathrm{x}}$ emissions, even when the radical pathway dominates. Because $\mathrm{NO}_{\mathrm{x}}$ emissions vary across time and space, the contribution of the $\mathrm{O}_{3}$ pathway has prevented the accurate evaluation of $\mathrm{O}_{3}$ levels and variability at certain sites. This phenomenon has also presented a barrier to comparisons of $\mathrm{O}_{3}$ levels between sites with different $\mathrm{NO}_{\mathrm{x}}$ concentrations (Kley et al., 1999).

In order to accurately measure the photochemical production of ozone, we followed the approach of Liu (1977) and defined " $\mathrm{O}_{3}+\mathrm{NO}_{2}+\mathrm{NO}_{\mathrm{z}}+\mathrm{O}$ " as "total oxidant concentrations" $\left(\mathrm{NO}_{\mathrm{z}}=\mathrm{NO}_{\mathrm{y}}-\mathrm{NO}_{\mathrm{x}}\right)$. In this study, we use " $\mathrm{O}_{3}+\mathrm{NO}_{2}$ " as an estimate of total oxidant concentrations, because atomic oxygen is an ultra-trace species in the troposphere, while $\mathrm{NO}_{\mathrm{z}}$ species interfere with $\mathrm{NO}_{2}$ measurements. The major advantage of analyzing $\mathrm{O}_{3}+\mathrm{NO}_{2}$ in addition to $\mathrm{O}_{3}$ is that $\mathrm{O}_{3}+\mathrm{NO}_{2}$ closely approximates total oxidant concentrations, and is therefore not affected by reactions between NO and ozone via the $\mathrm{O}_{3}$ pathway. In other words, " $\mathrm{O}_{3}+\mathrm{NO}_{2}$ " is a better measure of the true photochemical production rate of ozone.

\subsection{Trajectory cluster analysis}

To evaluate and compare circulation patterns, two-day backtrajectories following the 3-D wind components were calculated by means of the HYSPLIT4 (HYbrid Single-Particle 


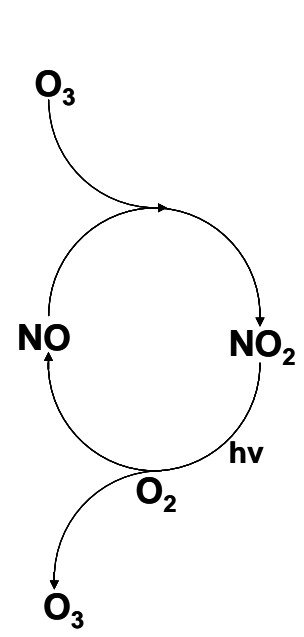

a

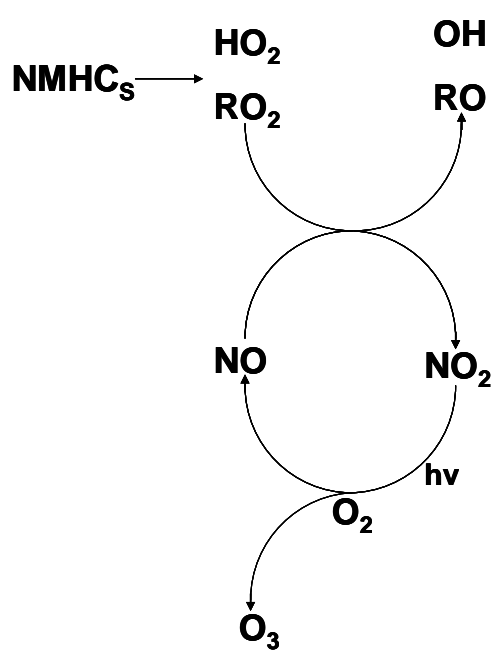

$\mathrm{b}$

Fig. 3. Schematics of the reactions involved in NO-to- $\mathrm{NO}_{2}$ conversion and $\mathrm{O}_{3}$ formation in (a) $\mathrm{NO}-\mathrm{NO}_{2}-\mathrm{O}_{3}$ systems in the absence of $\mathrm{NMHCs}$, and (b) $\mathrm{NO}-\mathrm{NO}_{2}-\mathrm{O}_{3}$ systems in the presence of NMHCs.

Lagrangian Integrated Trajectory, version 4.7, http://ready. arl.noaa.gov/HYSPLIT.php) model in isentropic coordinates, with 1-h time resolution. HYSPLIT is a well-known trajectory model, updated several times over the last two decades (Draxler and Taylor; 1982; Draxler, 1992; Draxler and Hess, 1997, 1998; Draxler and Rolph, 2003), and now is a complete system for computing simple trajectories for complex dispersion and deposition simulations using either puff or particle approaches. Gridded NCEP FNL (Final) Operational Global Analysis data (http://dss.ucar.edu/datasets/ds083.2/) were used in HYSPLIT calculations for the years 20012006. Its salient characteristics are a modest spatial resolution $\left(1^{\circ} \times 1^{\circ}\right)$, a temporal resolution of $6 \mathrm{~h}$, global coverage, and the inclusion of observations in the final analysis. The location of the backward trajectory end point was the Meteorological station (B1) with an altitude of $100 \mathrm{~m}$ above ground level (AGL), which was roughly at the center of these six sites.

The back trajectories technique is a useful tool in tracing source regions of air pollution and determining transport patterns at receptor sites in general. Although they do not represent exactly the path of an air parcel, they are suitable for identifying particular synoptic situations (Stohl et al., 1995; Stunder, 1996; Stohl, 1998). Considering the large uncertainty and limited significance of a single back trajectory (Stohl, 1998), a more reliable representation of the synoptic airflow in a given region can be achieved through the reconstruction and analysis of a large number of atmospheric trajectories. By doing so, errors in the individual trajectories tend to be averaged out. Cluster analysis is a simple statistical method that identifies homogeneous groups of members,

such as atmospheric trajectories, within large datasets. It has been demonstrated that clusters of back trajectories arriving at a specific location can serve as a surrogate of different synoptic circulation patterns (Dorling et al., 1992; Dorling and Davies, 1995).

In this study, a total of 13248 two-day trajectories (number of days times number of hours times number of years) were generated. A data reduction technique (P-mode PCA in SPSS v.13) was used to investigate fluctuations over consecutive 6-h intervals of a suite of latitude and longitude. The number of principal components (PC) to be retained was decided using two methods: graphically with a scree test and by examining a scree plot of eigennumber versus eigenvalue for a major break in the plot (Cattell, 1966), retaining PCs with an eigenvector value greater than 1.0 (Preisendorfer an Mobley, 1988). Both methods suggested retaining five PCs, which explained $95.6 \%$ of the variance in the original matrix.

To generate clustered trajectories, a non-hierarchical clustering algorithm (k-means algorithm in SPSS v.13) was applied to the principal component scores for each hour. The component scores matrix ( $13248 \mathrm{~h}$ times $5 \mathrm{PCs})$ obtained from PCA served as the input matrix for cluster analysis. The reduced size and the absence of co-linearity in the component scores matrix make it ideal data for clustering. This method was originally developed as an iterative classification process from a selected number of representative trajectories called "seeds" (Dorling et al., 1992). A sufficiently large number of synthetic seeds (30 trajectories) were created for Beijing, covering the spread of the individual trajectories. Each of the real PCs were then assigned to the seed that was closest in terms of the distance between their corresponding PCs. The "seed" or "average" PC of each cluster was then recalculated from its members, each time recalculating the cluster averages until all PCs were correctly assigned. The number of clusters was reduced by merging the two clusters whose average PCs are closest. Sudden changes in the total root-mean-square deviation as the number of clusters was reduced were interpreted as the merging of clusters of PCs that were significantly different in terms of the wind directions and speeds that they represented. This statistical test showed that the optimal number of clusters is 7 .

Figure 4 displays the trajectory clusters for these six years. Our chosen sites in Beijing are predominately influenced by air masses from the south, consistent with the powerful effects of the Asian summer monsoon. Nearly $45 \%$ of the air masses reaching Beijing originate from the south, approximately $30 \%$ from northern China, and $25 \%$ from the local area. These seven catalogs with different marks in Fig. 4 were then merged into two catalogs. The first cata$\log$, named Class I, is marked with crosses (+) in Fig. 4b, and its back-trajectories in the cluster are much shorter than the back-trajectories in other oriented clusters and stay relatively close to their origin. The second catalog, named Class II, included the rest six catalogs except Class I in Fig. 4. Through the second stage cluster analysis, longer and 

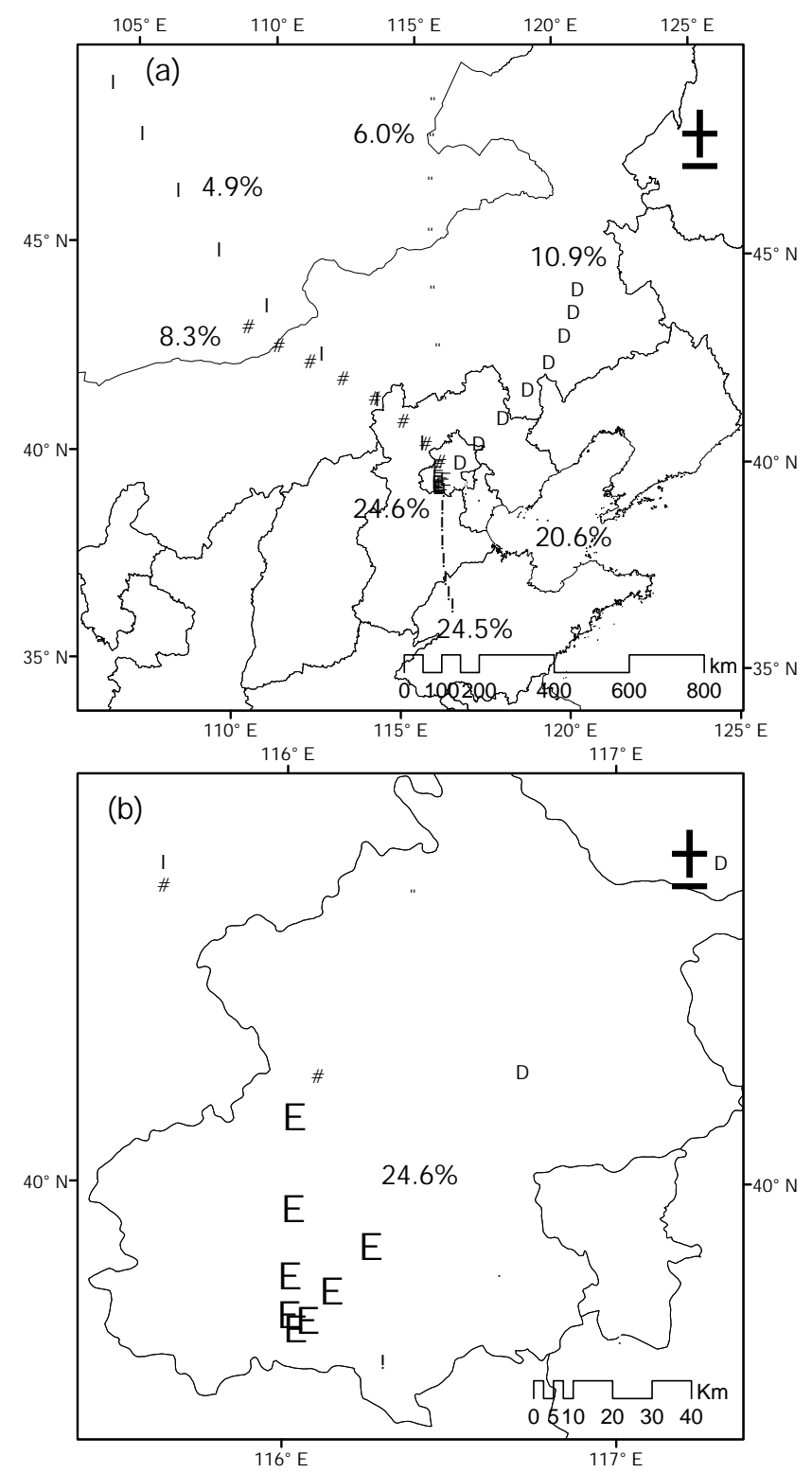

Fig. 4. Air mass backward trajectories for Beijing, (a) low resolution graph focused on the north of China, (b) high resolution graph focused on the Beijing area. Trajectory clusters are calculated based on trajectories from 2001-2006. 48-h trajectories are shown using 6-h steps.

shorter back-trajectories were disaggregated, as they approximately represent total pollutant concentrations due to regional contributions and local emission sources, respectively. Using this method, local circulation and regional transportation are disaggregated and average concentrations of Class I and Class II are calculated (Table 1), standing for the influence of local and regional pollutants, respectively.
Table 1. Disaggregated annual July-September average results for each species ${ }^{\mathrm{a}}$

\begin{tabular}{|c|c|c|c|c|c|c|c|}
\hline & 2001 & 2002 & 2003 & 2004 & 2005 & 2006 & $A v e^{d}$ \\
\hline \multicolumn{8}{|l|}{ Local $^{b}$} \\
\hline NO (ppbv) & 12 & 20 & 17 & 16 & 14 & 11 & 15 \\
\hline $\mathrm{NO}_{2}$ (ppbv) & 32 & 41 & 38 & 36 & 35 & 33 & 36 \\
\hline $\mathrm{O}_{3}$ (ppbv) & 31 & 24 & 32 & 28 & 35 & 33 & 31 \\
\hline $\mathrm{O}_{\mathrm{x}}(\mathrm{ppbv})$ & 63 & 65 & 71 & 65 & 70 & 67 & 67 \\
\hline $\mathrm{O}_{\mathrm{x} \_} \max (\mathrm{ppbv})^{\mathrm{e}}$ & 95 & 97 & 102 & 95 & 103 & 102 & 99 \\
\hline \multicolumn{8}{|l|}{ Regional $^{\mathrm{c}}$} \\
\hline NO (ppbv) & 15 & 21 & 18 & 17 & 13 & 11 & 16 \\
\hline $\mathrm{NO}_{2}$ (ppbv) & 34 & 38 & 34 & 33 & 30 & 28 & 33 \\
\hline $\mathrm{O}_{3}$ (ppbv) & 25 & 21 & 26 & 24 & 30 & 26 & 25 \\
\hline $\mathrm{O}_{\mathrm{x}}(\mathrm{ppbv})$ & 59 & 59 & 60 & 57 & 60 & 55 & 58 \\
\hline $\mathrm{O}_{\mathrm{x}} \max (\mathrm{ppbv})$ & 80 & 78 & 79 & 78 & 79 & 76 & 78 \\
\hline
\end{tabular}

a The concentrations of each species represent an average of measurements from all six representative stations in Beijing during July to September.

b Air masses from the local area (Class I).

${ }^{\mathrm{c}}$ Air masses from the regional area (Class II).

d Average values during 2001-2006.

e Daily maximum concentrations of $\mathrm{O}_{\mathrm{x}}$.

\section{Results and discussion}

This section is divided into four subsections. First, there is a brief comparison of pollutant concentrations at sites with different pollution characteristics. In the second and third subsections, annual July-September trends of average concentrations and diurnal variability in $\mathrm{O}_{3}$ and its related precursors are discussed, respectively. At last, $\mathrm{NO}_{\mathrm{x}}$ and $\mathrm{NMHCs}$ emissions, cluster trajectories analysis and meteorological data are applied to show the interpretations of ozone, total oxidants concentration changes and observed interannual variability, respectively.

\subsection{Comparison of pollutant concentrations at sites with different pollution characteristics}

Table 2 summarizes pollutant data recorded from sites A1A6 in July-September 2001-2006. The A1 site, located in the center of Beijing, is generally exposed to greater concentrations of vehicular $\mathrm{NO}_{\mathrm{x}}$ emissions. The reaction of more ozone with vehicular $\mathrm{NO}$ results in lower ozone levels at $\mathrm{A} 1$ than at the other sites, while lower combined $\mathrm{NO}_{\mathrm{x}}$ emissions cause higher ozone levels at the A6 site. This inverse spatial relationship between ozone and $\mathrm{NO}_{\mathrm{x}}$ levels is consistent with the findings of other groups (Bower et al., 1994; Mckendry, 1993; Wu and Chan, 2000; Chou et al., 2006). Siteto-site variability is clearly closely related to site characteristics. Differences in annual average ozone concentrations among the various sites were determined by taking into account differences in the rates of surface ozone elimination mechanisms at the respective locations. However, the potential for surface ozone production in ground level was found 


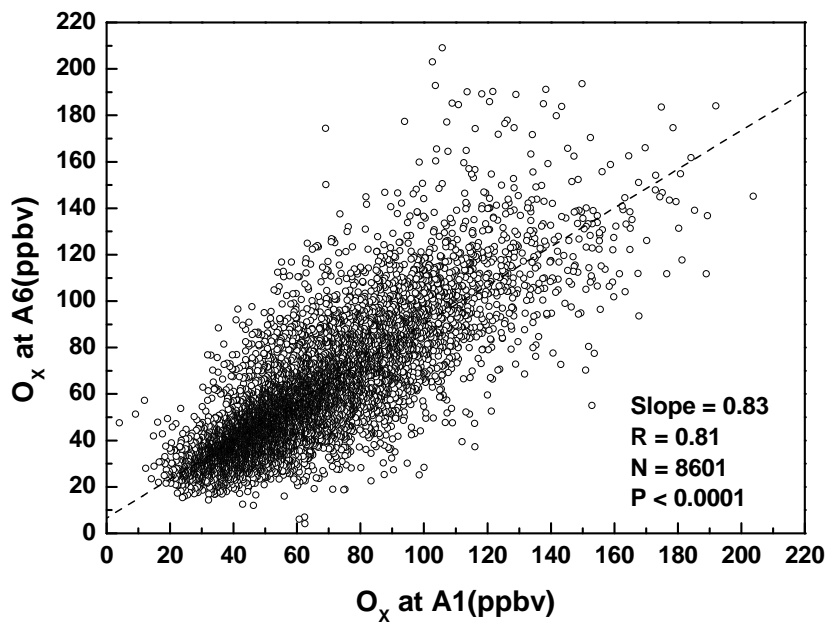

Fig. 5. The correlation between $\mathrm{O}_{\mathrm{x}}$ concentrations at sites $\mathrm{A} 1$ and A6 during 2001-2006.

to be roughly equivalent across all of the 6 sites in downtown Beijing. Figure 5 shows scatter plots of $\mathrm{O}_{\mathrm{x}}$ concentrations at A1 and A6. A first-order linear regression of $\mathrm{O}_{\mathrm{x}}$ concentrations at these two points identified a strong correlation with a slope of 0.83 . Possible explanations for variations in pollutant concentrations between different sites have been discussed by Clapp and Jenkin (2001). Explanations include variability in the fractional contributions of $\mathrm{NO}_{2}$ to emitted $\mathrm{NO}_{\mathrm{x}}$, differences that might be linked to different vehicle fleet compositions, and different driving conditions around each site. Although both concentrations exhibit small siteto-site variations, $\mathrm{O}_{\mathrm{x}}$ concentrations are thought to represent regional total oxidant levels better than $\mathrm{O}_{3}$ concentrations.

\subsection{Annual July-September trends with interannual variability}

Table 3 lists the trends in average annual July-September concentrations of $\mathrm{NO}, \mathrm{NO}_{2}, \mathrm{NO}_{\mathrm{x}}, \mathrm{O}_{3}, \mathrm{O}_{3}$ max (daily maximum $1 \mathrm{~h}$ ozone), and $\mathrm{O}_{\mathrm{x}}$ in these six sites during the period 2001-2006. All the sites showed downward trends (ranged from -2.1 to $-8.0 \mathrm{ppbv} / \mathrm{yr}$ for $\mathrm{NO}_{\mathrm{x}}$ mean) in the period of 2002-2006. Five sites showed upward trends (ranged from 1.0 to $2.2 \mathrm{ppbv} / \mathrm{yr}$ for ozone mean and from 1.5 to $3.2 \mathrm{ppbv} / \mathrm{yr}$ for ozone daily maximum) during 20012006. On the other hand, the A6 station showed downward trends $(-2.0 \mathrm{ppbv} / \mathrm{yr}$ for ozone mean and $-3.9 \mathrm{ppbv} / \mathrm{yr}$ for ozone daily maximum) due to the relocation of industrial areas. Moreover, two each of the six sites showed upward, downward and no significant trends for $\mathrm{O}_{\mathrm{x}}$. When average concentrations of these six sites were considered, linear regressions showed that concentrations of $\mathrm{NO}, \mathrm{NO}_{2}$, and $\mathrm{NO}_{\mathrm{x}}$ decreased at rates of $2.0 \pm 0.4 \mathrm{ppbv} / \mathrm{yr}$ (slope \pm standard deviation of the mean for the first order linear regression), $1.9 \pm 0.1 \mathrm{ppbv} / \mathrm{yr}$, and $3.9 \pm 0.5 \mathrm{ppbv} / \mathrm{yr}$ since 2002 ,
Table 2. Summary of concentrations between 2001 and 2006 at six sites $^{\mathrm{a}}$.

\begin{tabular}{lrrrrrr}
\hline & $\mathrm{A} 1$ & $\mathrm{~A} 2$ & $\mathrm{~A} 3$ & $\mathrm{~A} 4$ & $\mathrm{~A} 5$ & $\mathrm{~A} 6$ \\
\hline Ave $^{\mathrm{b}}$ & & & & & & \\
$\mathrm{NO}_{\mathrm{x}}$ & 67 & 47 & 43 & 50 & 50 & 36 \\
$\mathrm{NO}_{2}$ & 42 & 33 & 31 & 34 & 33 & 28 \\
$\mathrm{O}_{3}$ & 22 & 30 & 30 & 22 & 25 & 32 \\
$\mathrm{O}_{\mathrm{x}}$ & 64 & 63 & 61 & 57 & 58 & 60 \\
$\mathrm{Max}^{\mathrm{c}}$ & & & & & & \\
$\mathrm{NO}_{\mathrm{x}}$ & 144 & 113 & 98 & 112 & 116 & 78 \\
$\mathrm{NO}_{2}$ & 54 & 66 & 74 & 59 & 60 & 75 \\
$\mathrm{O}_{3}$ & 70 & 60 & 56 & 58 & 57 & 50 \\
$\mathrm{O}_{\mathrm{x}}$ & 101 & 98 & 100 & 91 & 91 & 97 \\
$\mathrm{Min}^{\mathrm{d}}$ & & & & & & \\
$\mathrm{NO}_{\mathrm{x}}$ & 30 & 18 & 16 & 21 & 23 & 15 \\
$\mathrm{NO}_{2}$ & 4 & 8 & 5 & 3 & 4 & 6 \\
$\mathrm{O}_{3}$ & 23 & 15 & 13 & 18 & 17 & 12 \\
$\mathrm{O}_{\mathrm{x}}$ & 38 & 40 & 34 & 33 & 35 & 36 \\
\hline
\end{tabular}

a The concentrations of each species represent an average of measurements from each station during July to September.

${ }^{\mathrm{b}}$ Average concentrations in ppbv.

${ }^{\mathrm{c}}$ Average daily maximum concentrations in ppbv.

$\mathrm{d}$ Average daily minimum concentrations in ppbv.

respectively (Fig. 6a). Meanwhile, concentrations of $\mathrm{O}_{3}$ and $\mathrm{O}_{3}$ max increased by $1.1 \pm 0.5 \mathrm{ppbv} / \mathrm{yr}$ and $1.6 \pm 0.7 \mathrm{ppbv} / \mathrm{yr}$, respectively. However, concentrations of $\mathrm{O}_{\mathrm{x}}$ showed no significant trends. Additionally, concentrations of $\mathrm{O}_{3}, \mathrm{O}_{3} \_$max and $\mathrm{O}_{\mathrm{x}}$ showed an interannual variability in which odd-year concentrations exceeded those for even years, with values of $2.0 \mathrm{ppbv}, 5.9 \mathrm{ppbv}$ and $4.0 \mathrm{ppbv}$, respectively (Fig. 6b).

\subsection{Annual July-September trends of diurnal variability in $\mathrm{O}_{3}$ concentration and in related precursors}

Figure $7 \mathrm{a}-\mathrm{d}$ illustrate the average diurnal variation in the hourly averages of $\mathrm{NO}_{2}, \mathrm{NO}, \mathrm{O}_{\mathrm{x}}$ and $\mathrm{O}_{3}$, respectively, in Beijing during 2001-2006. Maximum mean NO concentrations are observed between 07:00 $\mathrm{h}-08: 00 \mathrm{~h}$ and at midnight (Fig. 7b). From 07:00 h on, $\mathrm{NO}$ is converted to $\mathrm{NO}_{2}$ via reaction with $\mathrm{O}_{3}$, while $\mathrm{NO}_{2}$ is converted back to $\mathrm{NO}$ during daylight hours as a result of photolysis, which also leads to the regeneration of $\mathrm{O}_{3}$ (Jenkin and Clemitshaw, 2000). During the early daylight hours, $\mathrm{NO}$ concentrations rise, mainly due to the increase in traffic. Figure 7a shows that the $\mathrm{NO}_{2}$ production rates are greatest near 08:00 h (after dawn), a result that can be explained by reactions that involve NO and hydrocarbons (Finlayson-Pitts and Pitts, 1986; Seinfeld and Pandis, 1998). After 08:00 h, [NO] diminishes until it reaches its lowest levels between 14:00 h-15:00 h (Fig. 7b). This NO decrease matches the increase in $\mathrm{O}_{3}$ levels. The highest $\mathrm{O}_{3}$ and $\mathrm{O}_{\mathrm{x}}$ values are evident between 14:00 h and 

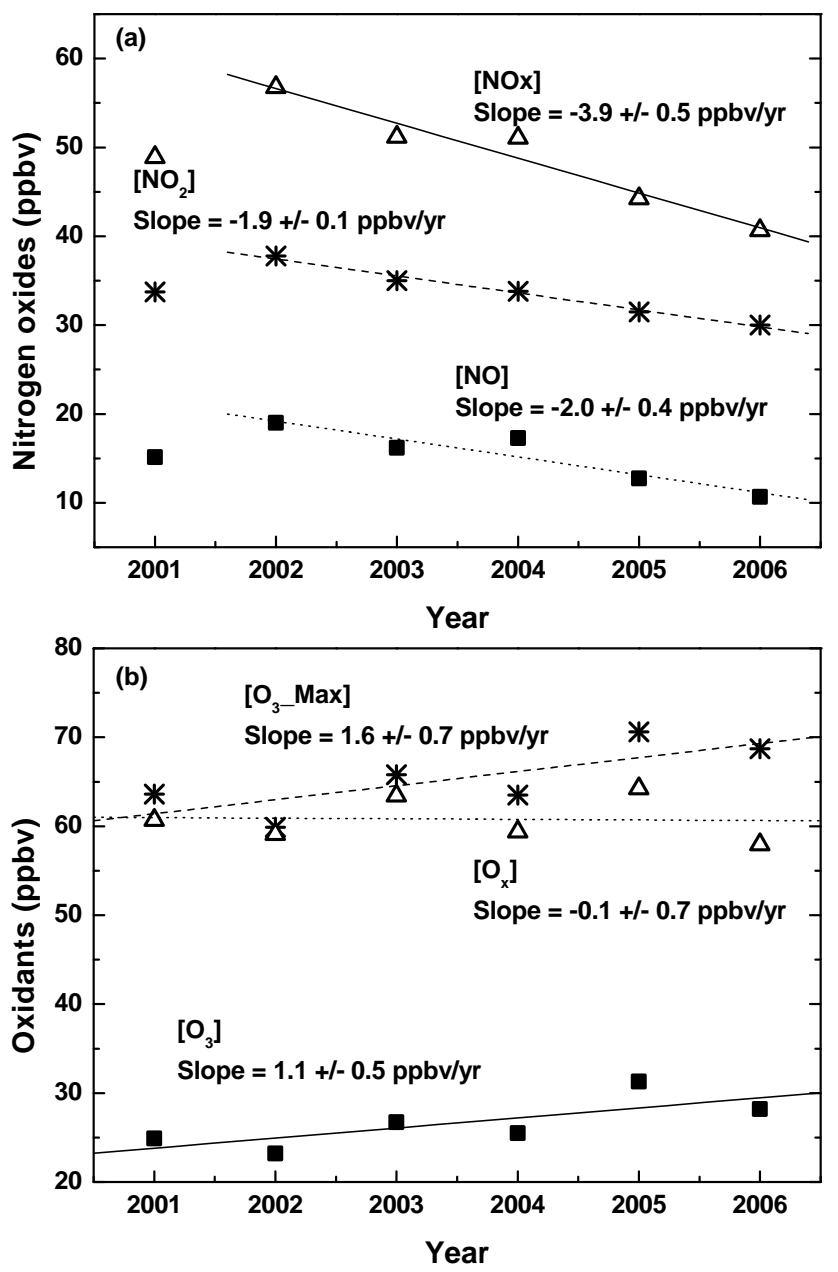

Fig. 6. Concentration trends for (a) $\mathrm{NO}, \mathrm{NO}_{2}, \mathrm{NO}_{\mathrm{x}}$, (b) $\mathrm{O}_{3}, \mathrm{O}_{\mathrm{x}}$, 2001-2006. The concentration of each species represents an average of measurements from all six representative stations in Beijing from July to September.

15:00 h, after which $\mathrm{O}_{3}$ and $\mathrm{O}_{x}$ levels decrease gradually (Fig. $7 \mathrm{c}-\mathrm{d}$ ). $\mathrm{NO}_{2}$ decreases as $\mathrm{O}_{3}$ increases, with rising concentrations after 15:00 h. NO increases with the onset of evening traffic, reaching its highest value between 01:00 h and 03:00 h. As $\mathrm{NO}$ reacts with $\mathrm{O}_{3}$, ozone concentrations fall. Another factor that influences pollutant concentrations is the height of the mixing layer over the city. From $08: 00 \mathrm{~h}$ to $14: 00-15: 00 \mathrm{~h}$, increasing global radiation and an increase in the height of the mixing layer (Ulke and Mazzeo, 1998) lead to a decrease in hourly $\mathrm{NO}_{\mathrm{x}}$ concentrations and a trend toward increasing $\mathrm{O}_{3}$. At night, low mixing layer heights may allow hourly $\mathrm{NO}_{\mathrm{x}}$ concentrations to increase.

Figure 8a shows the annual July-September changes in the daily average morning maximum of the relative diurnal variations of $\mathrm{NO}$ and $\mathrm{NO}_{2}$. Daily average morning maximum values for $\mathrm{NO}$ and $\mathrm{NO}_{2}$ decrease linearly at rates of $3.4 \mathrm{ppbv} / \mathrm{yr}$ and $2.5 \mathrm{ppbv} / \mathrm{yr}$, respectively, after 2002, suggesting that mobile emissions of $\mathrm{NO}_{\mathrm{x}}$ in Beijing may have
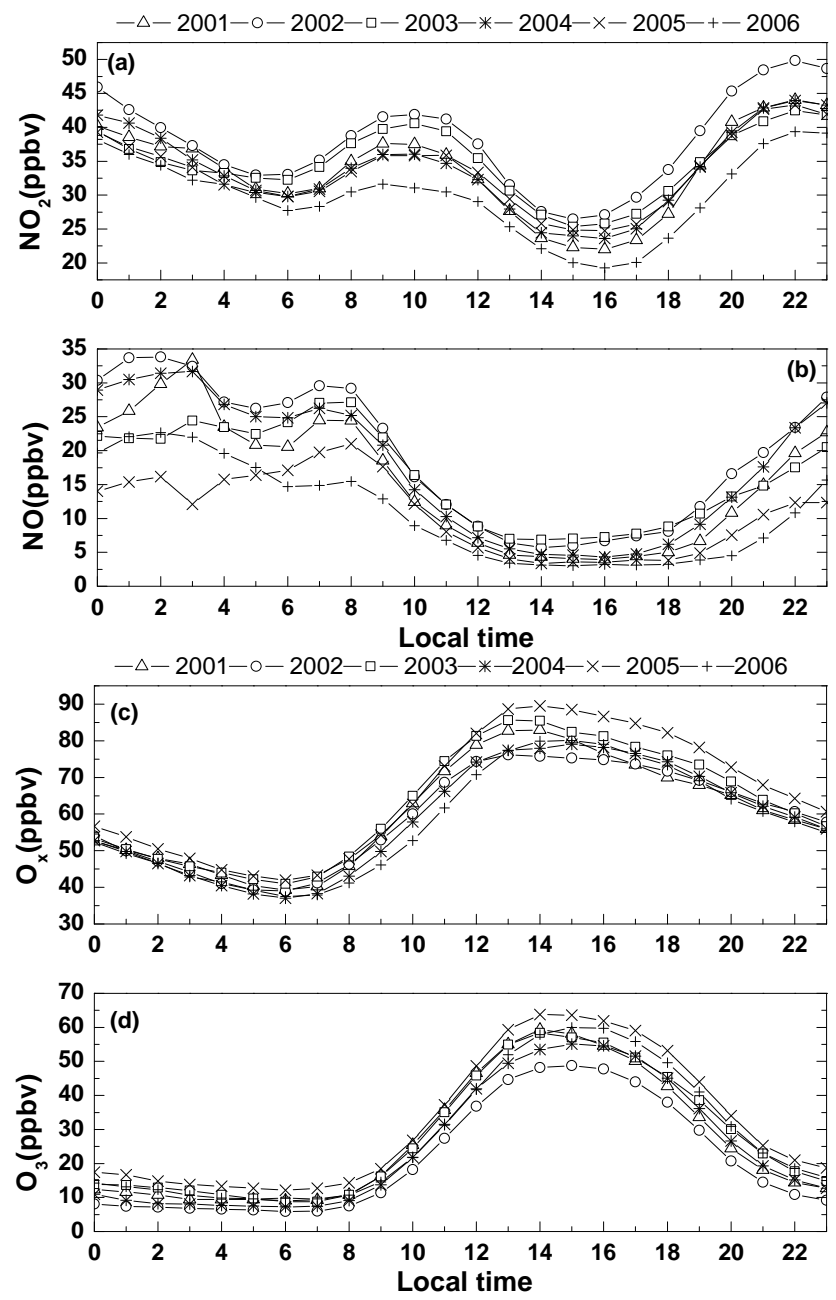

Fig. 7. Diurnal trends of $\mathrm{NO}_{2}$ (a), $\mathrm{NO}(\mathbf{b}), \mathrm{O}_{\mathrm{x}}$ (c), $\mathrm{O}_{3}$ (d), 20012006. The concentration of each species represents an average of measurements taken from the six representative stations in Beijing.

decreased significantly over the period 2002-2006. Figure $8 \mathrm{~b}$ shows the annual July-September changes in the daily average maximum and minimum of the relative diurnal variations of oxidants in Beijing. Maximum and minimum $\mathrm{O}_{3}$ concentrations increased linearly at rates of $1.6 \mathrm{ppbv} / \mathrm{yr}$ and $0.7 \mathrm{ppbv} / \mathrm{yr}$, respectively. Maximum and minimum $\mathrm{O}_{\mathrm{x}}$ concentrations varied linearly at rates of $1.0 \mathrm{ppbv} / \mathrm{yr}$ and $-0.1 \mathrm{ppbv} / \mathrm{yr}$, respectively. The increase in daily maximum $\left[\mathrm{O}_{\mathrm{x}}\right]$ relative to constant daily minimum concentrations suggests increasing diurnal variations in ozone concentrations throughout Beijing.

From the above analysis, we arrive at two major conclusions. First, given that the morning maxima of $\mathrm{NO}$ and $\mathrm{NO}_{2}$ concentrations reflect the mobile emission of $\mathrm{NO}_{\mathrm{x}}$, we conclude that the increasing daily minimum $\left[\mathrm{O}_{3}\right]$ is likely due to reactions with the decreasing daily morning [NO], accounting for the constant daily minimum $\left[\mathrm{O}_{\mathrm{x}}\right]$ observed. Second, the increase of the daily maximum $\left[\mathrm{O}_{\mathrm{x}}\right]$, relative constancy of 
Table 3. Annual July-September mean $\mathrm{NO}_{\mathrm{x}}$ and oxidants concentration trends in the six sites.

\begin{tabular}{lrrrrrr}
\hline sites & $\begin{array}{r}\mathrm{NO} \\
(\mathrm{ppbv} / \mathrm{yr})\end{array}$ & $\begin{array}{r}\mathrm{NO}_{2} \\
(\mathrm{ppbv} / \mathrm{yr})\end{array}$ & $\begin{array}{r}\mathrm{NO}_{\mathrm{x}} \\
(\mathrm{ppbv} / \mathrm{yr})\end{array}$ & $\begin{array}{r}\mathrm{O}_{3} \\
(\mathrm{ppbv} / \mathrm{yr})\end{array}$ & $\begin{array}{r}\mathrm{O}_{\mathrm{x}} \\
(\mathrm{ppbv} / \mathrm{yr})\end{array}$ & $\begin{array}{r}\mathrm{O}_{3} \max \\
(\mathrm{ppbv} / \mathrm{yr})\end{array}$ \\
\hline $\mathrm{A} 1$ & $-4.8( \pm 1.2)$ & $-3.2( \pm 0.7)$ & $-8.0( \pm 1.9)$ & $1.7( \pm 1.0)$ & $-1.2( \pm 2.1)$ & $2.7( \pm 2.4)$ \\
$\mathrm{A} 2$ & $-2.2( \pm 0.6)$ & $-1.1( \pm 0.3)$ & $-3.3( \pm 0.9)$ & $1.0( \pm 1.3)$ & $0.2( \pm 1.4)$ & $1.5( \pm 1.2)$ \\
$\mathrm{A} 3$ & $-1.2( \pm 0.3)$ & $-1.3( \pm 0.4)$ & $-2.5( \pm 0.7)$ & $1.7( \pm 1.1)$ & $1.0( \pm 2.4)$ & $3.0( \pm 2.6)$ \\
$\mathrm{A} 4$ & $-1.4( \pm 1.3)$ & $-4.2( \pm 0.7)$ & $-5.4( \pm 2.0)$ & $1.9( \pm 1.9)$ & $0.1( \pm 3.0)$ & $3.1( \pm 2.2)$ \\
$\mathrm{A} 5$ & $-1.7( \pm 1.0)$ & $-0.5( \pm 0.5)$ & $-2.2( \pm 1.5)$ & $2.2( \pm 1.5)$ & $1.4( \pm 2.0)$ & $3.2( \pm 2.3)$ \\
A6 & $-0.7( \pm 0.3)$ & $-1.4( \pm 0.9)$ & $-2.1( \pm 1.2)$ & $-2.0( \pm 1.6)$ & $-1.8( \pm 2.2)$ & $-3.9( \pm 2.1)$ \\
Average & $-2.0( \pm 0.4)$ & $-1.9( \pm 0.1)$ & $-3.9( \pm 0.5)$ & $1.1( \pm 0.5)$ & $-0.1( \pm 0.7)$ & $1.6( \pm 0.7)$ \\
\hline
\end{tabular}

the daily minimum $\left[\mathrm{O}_{\mathrm{x}}\right]$, and increase of the daily amplitude of $\left[\mathrm{O}_{\mathrm{x}}\right]$ reflect enhanced local photochemical production.

\subsection{Interpretation of concentration changes}

\subsubsection{Interpretation of ozone concentration changes}

Concentrations of $\mathrm{NO}_{\mathrm{x}}$ species, which are known $\mathrm{O}_{3}$ precursors, decreased significantly after 2002 (Table 3). However, over the same period, we also observed increased $\mathrm{O}_{3}$ concentrations (Table 3). Seinfeld and Pandis (1998) reported worsening photochemical air pollution under decreasing concentrations of $\mathrm{NO}_{\mathrm{x}}$ precursors in metropolitan areas, and pointed to changes in the NMHCs/ $\mathrm{NO}_{\mathrm{x}}$ ratio as a possible explanation. In the absence of direct measurements of NMHCs concentrations, we use the emission ratio of NMHCs to $\mathrm{NO}_{\mathrm{x}}$ in Beijing to explore this hypothesis. Figure 1 illustrates the increasing emission of NMHCs and the decreasing emission of $\mathrm{NO}_{\mathrm{x}}$ in Beijing. Given the increasing emission ratio of NMHCs to $\mathrm{NO}_{\mathrm{x}}$, the observed trends of average and maximum $\left[\mathrm{O}_{3}\right]$ seem consistent with a system in which Seinfeld's $\mathrm{NMHCs} / \mathrm{NO}_{\mathrm{x}}$ hypothesis describes the relationship between pollution controls and ozone formation rates.

\subsubsection{Interpretation of total oxidant concentration changes}

$\mathrm{NO}, \mathrm{NO}_{2}, \mathrm{O}_{3}, \mathrm{O}_{\mathrm{x}}$, and $\mathrm{O}_{\mathrm{x}}$ max were calculated for each year by local area and by region based on trajectory cluster analysis. While $\mathrm{NO}$ concentrations from all sources were nearly identical, $\mathrm{NO}_{2}, \mathrm{O}_{3}, \mathrm{O}_{\mathrm{x}}$, and $\mathrm{O}_{\mathrm{x}-\max }$ concentrations in local air masses exceeded those of air masses from regional sources by more than 3 ppbv, 6 ppbv, 9 ppbv and 21 ppbv, respectively (Table 1). Figure 9a shows trends in the daily maximum and average concentrations of total oxidants in local air masses and 75th percentile concentrations of daily maximum aggregate total oxidants over the 2001-2006 period. In contrast to the nearly constant annual July-September average concentrations of total oxidants (Table 1), the maxima and average exhibit a significant upward trend, with slopes of $1.3 \pm 0.6 \mathrm{ppbv} / \mathrm{yr}$ and $0.8 \pm 0.6 \mathrm{ppbv} / \mathrm{yr}$, respectively (Fig. 9a).
Because the highest $25 \%$ of concentrations were measured primarily at times when air masses originated from the Beijing urban area (Table 1), the 75th percentile concentration measurements also show an increasing trend at a rate of $1.2 \pm 0.5 \mathrm{ppbv} / \mathrm{yr}$. Given the increasing emission of NMHCs and the decreasing emission of $\mathrm{NO}_{\mathrm{x}}$, an increasing photochemical production rate of $\mathrm{O}_{\mathrm{x}}$ is to be expected. Therefore, the fact that total oxidant concentrations remained largely constant during the 2001-2006 period is of great interest.

The concentration of $\mathrm{O}_{\mathrm{x}}$ at a given location is made up of two contributions: a regional contribution, equivalent to the background $\mathrm{O}_{\mathrm{x}}$ concentration, and a local contribution, which depends on the level of primary pollution in the area (Nicolas et al., 2005). Considering the consistency between the trends of peak concentrations for oxidants and their precursors, we can infer that oxidant production from photochemical reactions in Beijing's local air masses likely increased during the 2001-2006 period. Hence, the contradictory observations of constant average oxidant levels over this period must be due to unknown factors that exactly offset this increased $\mathrm{O}_{x}$ production. The decrease in regional oxidant levels was identified as the most likely source of this phenomenon. The data in Fig. 9b suggest a decreasing trend in the daily maximum and average total oxidant concentrations from regional area sources. In terms of annual July-September averages, the concentrations of daily maximum and average $\mathrm{O}_{\mathrm{x}}$ decreased by $0.6 \pm 0.3 \mathrm{ppbv} / \mathrm{yr}$ and $0.5 \pm 0.3 \mathrm{ppbv} / \mathrm{yr}$, respectively, during the 2001-2006 period. We speculate that decreasing regional background oxidant concentrations may have offset the increased local average oxidant production over this period, accounting for the constant average oxidant levels observed.

\subsubsection{Interpretation of the observed interannual variability}

In addition to precursor emissions, $\mathrm{O}_{3}$ concentrations in urban areas are directly tied to meteorological conditions, such as maximum temperatures, solar intensity, precipitation, and stagnation. NRC (1991), Davidson (1993), and Wakamatsu et al. (1996) identified a positive relationship between 

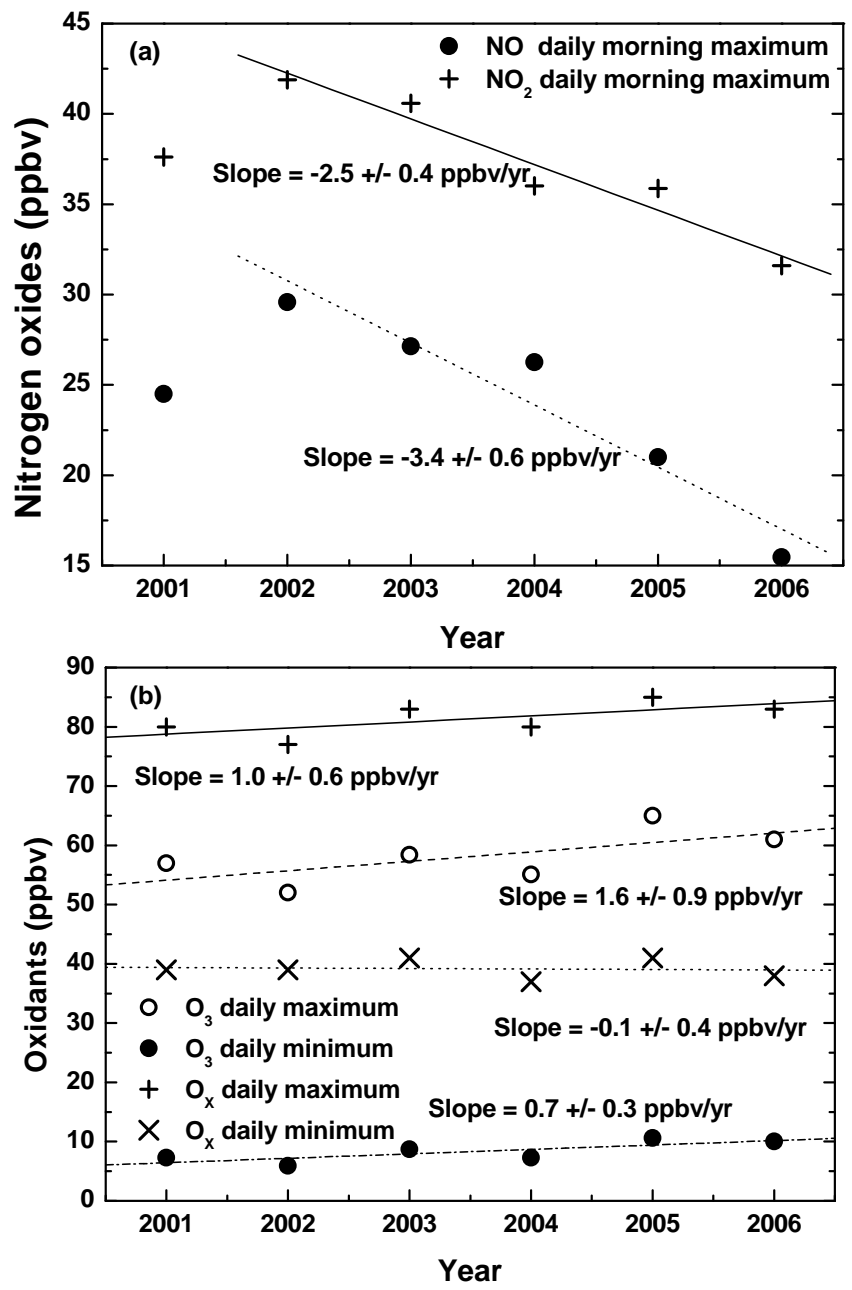

Fig. 8. Annual July-September trends (a) in the daily morning maximum concentrations of $\mathrm{NO}, \mathrm{NO}_{2}$ and (b) in the daily average maximum and minimum concentrations of $\mathrm{O}_{3}, \mathrm{O}_{\mathrm{x}}$, in 2001-2006. The concentration of each species represents an average of measurements taken from the six representative stations in Beijing.

ambient maximum temperature and daily maximum $\mathrm{O}_{3}$ concentrations. Liu, et al. (1994) also indicated that the absence of precipitation is a crucial parameter accompanying elevated noontime ozone levels. The relationship between the daily average maximum temperatures, total precipitation, and $\mathrm{O}_{3}$ concentrations during 2001-2006 is shown in Fig. 10. A positive correlation is evident between the daily average maximum temperature and $\mathrm{O}_{3}$ concentration, while increased precipitation is found to negatively impact $\mathrm{O}_{3}$ production. These two factors appear to account for the observed interannual variability of $\mathrm{O}_{3}$ and $\mathrm{O}_{x}$ concentrations in Beijing.

Additionally, the tropical sea surface temperature (SST) and the East Asian summer monsoon are related in a system resembling the tropical biennial oscillation (TBO) described by Meehl $(1987,1997)$ and others. There is also a correlation between the monsoon and the tropical western Pacific
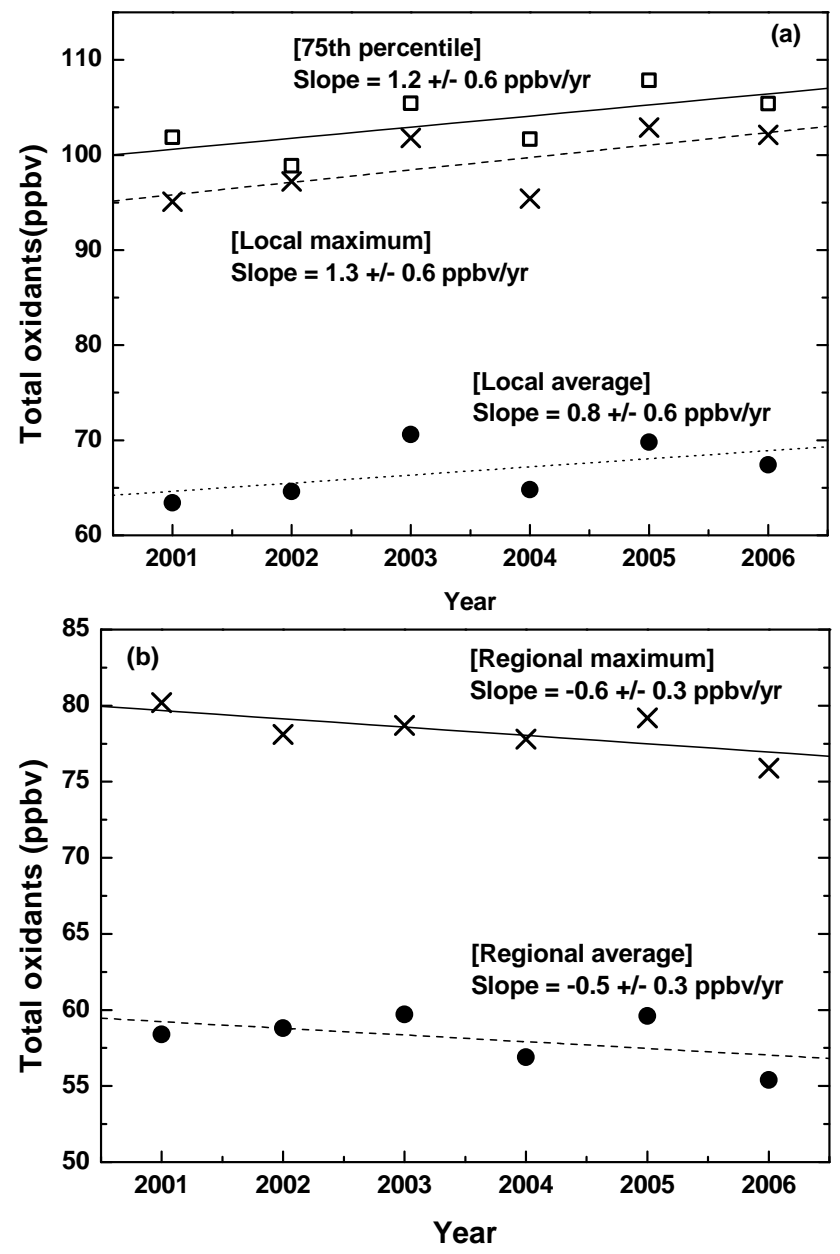

Fig. 9. Annual July-September trends of (a) daily maximum and average total oxidant concentrations from local area sources (Class I) and 75th percentile daily maximum total oxidant concentrations from all sources, and (b) daily maximum and average total oxidant concentrations from regional area sources (Class II) during the 2001-2006 period. The concentration of each species represents the average of measurements across all six representative stations in Beijing.

SST that is opposite to that of the eastern Pacific SST (Wang et al., 2001). In this TBO relationship, the summer monsoon in China will be strong after an El Niño-like condition in the preceding winter. The SST anomalies change sign in northern spring just before this strong monsoon starts, and in the following year, a weak summer monsoon will follow a La Niña-like condition in the winter. This TBO relationship of the summer monsoon in China resulted in the interannual variability of temperature and precipitation. Considering the relationship between meteorology and ozone mixing ratio, this interannual variability will likely continue to occur on alternate years. However, ozone and precursors should be observed in Beijing continuously in order to confirm this assertion. 


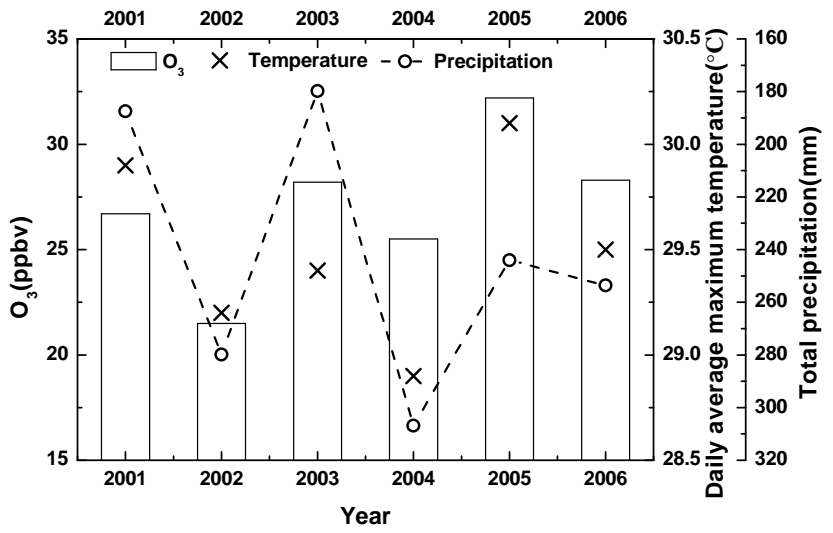

Fig. 10. Annual July-September trends of daily average maximum temperatures, total precipitation and $\mathrm{O}_{3}$ concentrations in JulySeptember during 2001-2006.

\section{Conclusions}

This work aimed to identify the reasons for increased $\mathrm{O}_{3}$ concentrations by analyzing the relationship between $\mathrm{O}_{3}$ and its precursors. We tracked $\mathrm{O}_{3}+\mathrm{NO}_{2}$ in addition to $\mathrm{O}_{3}$ because the former is approximately equal to the total oxidant concentration and can reveal regional atmospheric oxidation capacity better than $\mathrm{O}_{3}$ alone.

We present annual July-September trends in the concentrations of surface ozone and related components in Beijing. Our results suggest a decrease in average $\left[\mathrm{NO}_{\mathrm{x}}\right]$ and an increase in average $\left[\mathrm{O}_{3}\right]$, with significant site-to-site variability. Our data also show a relatively constant average $\left[\mathrm{O}_{\mathrm{x}}\right]$, with minimal site-to-site variability. Furthermore, we identified an increase in the daily amplitude of diurnal concentration variations, in the context of a interannual variability for $\mathrm{O}_{3}$ and $\mathrm{O}_{\mathrm{x}}$. All of these trends lead us to three major conclusions:

1. Beijing's surface ozone variability is accentuated primarily by a decrease in $\mathrm{NO}_{\mathrm{x}}$ emissions and an increase in NMHCs emissions.

2. A decrease in regional $\mathrm{O}_{x}$ concentrations seems to counteract increasing local $\mathrm{O}_{\mathrm{x}}$ production levels, and it leads to near-constant $\mathrm{O}_{\mathrm{x}}$ levels in Beijing.

3. The influence of meteorological factors is the main explanation for the observed interannual variability.

Increasing daily maximum ozone concentrations may exert negative impacts on human health and vegetation. Therefore, control measures should be taken to avoid further exacerbation of ozone pollution. Measures should include efforts to reduce NMHCs emissions.
Acknowledgements. This work was supported by a grant from the National Basic Research Program (No. 2007CB407303), the Knowledge Innovation Program of the Chinese Academy of Sciences (approved \# KZCX1-YW-06-01), and the National Natural Science Fund (No. 40675073).

Edited by: J. G. Murphy

\section{References}

Akimoto, H.: Global air quality and pollution, Science, 302, 17161719, 2003.

Atkinson, R.: Atmospheric chemistry of VOCs and $\mathrm{NO}_{\mathrm{x}}$, Atmos. Environ., 34, 2063-2101, 2000.

Beijing Municipal Bureau of Statistics: Beijing Statistical Yearbook, http://www.bjstats.gov.cn/tjnj/2008-tjnj/, last access: 19 November 2009, 2008.

Beijing Municipal Environmental Protection Bureau: Regional coal-burning pollution control study during the 11th Five-Year Plan in Beijing, 174 pp., 2007.

Beijing Municipal Environmental Protection Bureau: Air quality standards for Strategic Studies of Beijing, 227 pp., 2006.

Bower, J. S., Stecenson, K. J., Broughton, G. F. J., et al.: Assessing recent surface ozone concentrations in the UK, Atmos. Environ., 28, 115-128, 1994.

Cattell, R. B.: The scree test for the number of factors, Multivariate, Behav. Res., 1, 245-276, 1966.

Chou, C. C.-K., Liu, S. C., Lin, C.-Y., et al.: The trend of surface ozone in Taipei, Taiwan, and its causes: Implications for ozone control strategies, Atmos. Environ., 40, 3898-3908, 2006.

Clapp, L. J. and Jenkin, M. E.: Analysis of the relationship between ambient levels of $\mathrm{O}_{3}, \mathrm{NO}_{2}$ and $\mathrm{NO}$ as a function of $\mathrm{NO}_{\mathrm{x}}$ in the UK, Atmos. Environ., 35, 6391-6405, 2001.

Davidson, A.: Update on ozone trend in California's south coast air basin, J. Air Waste Manage., 43, 226-227, 1993.

Dorling, S. R. and Davies, T. D.: Extending cluster analysissynoptic meteorology links to characterize chemical climates at six northwest European monitoring stations, Atmos. Environ., 29, 145-167, 1995

Dorling, S. R., Davies, T. D., and Pierce, C. E.: Cluster analysis: a technique for estimating the synoptic meteorological controls on air and precipitation chemistry method and applications, Atmos. Environ., 26, 2575-2581, 1992.

Draxler, R. R. and Taylor, A. D.: Horizontal dispersion parameters for longrange transport modeling, J. Appl. Meteorol., 21, 367372, 1982.

Draxler, R. R.: Hybrid single-particle Lagrangian integrated trajectories (HYSPLIT): Version 3.0 - User's guide and model description, NOAA Tech. Memo. ERL ARL-195, 26 pp. and Appendices, 1992.

Draxler, R. R. and Hess, G. D.: Description of the HYSPLIT 4, modeling system, NOAA Tech. Memo. ERL ARL-224, NOAA, Sliver Spring, Md, 24 pp., 1997.

Draxler, R. R. and Hess, G. D.: An overview of the HYSPLIT 4 modeling system for trajectories, dispersion, and deposition, Aust. Meteorol. Mag., 47, 295-308, 1998.

Draxler, R. R. and Rolph, G. D.: NOAA ARL HYSPLIT Model, NOAA Air Resources Laboratory, available at http://ready.arl. noaa.gov/HYSPLIT.php, last access: 19 November 2009, 2003. 
Finlayson-pitts, B. J. and Pitts, J. N.: Atmospheric Chemistry: Fundamentals and experimental Techniques, Wiley, New York, 1097 pp., 1986.

Finlayson-pitts, B. J. and Pitts, J. N.: Chemistry of the upper and lower troposphere, theory, experiment, and applications, San Diego: Academic Press, 969 pp., 2000.

Houghton, J. T., Ding, Y., Griggs, D. J., et al.: Intergovernmental panel on Climate Change(IPCC), Climate Change 2001: The science of Climate Change, Cambridge Univ. Press, New York, USA, 881 pp., 2001.

Jenkin, M. E. and Clemitshaw, K. C.: Ozone and other secondary photochemical pollutants chemical processes governing the formation in the planetary boundary layer, Atmos. Environ., 34, 2499-2577, 2000.

Kley, D., Kleinmann, M., Sanderman, H., et al.: Photochemical oxidants: state of the science, Environ. Pollut., 100, 19-42, 1999.

Liu, C. M., Huang, C.-Y., Shieh, S.-L., et al.: Important meteorological parameters for ozone episodes experienced in the Taipei basin, Atmos. Environ., 38(1), 159-173, 1994.

Liu, S. C.: Possible effects on tropospheric $\mathrm{O}_{3}$ and $\mathrm{OH}$ due to $\mathrm{NO}$ emissions, Geophys. Res. Lett., 4, 325-328, 1977.

Ma, Y. L. and Zhang, Y. H.: The Study on Pollution of Atmospheric Photochemical oxidants in Beijing, Res. Environ. Sci., 13(1), 1417, 2000.

McKendry, I. G.: Ground-level ozone in Montreal, Canada, Atmos. Environ., 27B, 93-103, 1993.

Meehl, G. A.: The annual cycle and interannual variability in the tropical Pacific and Indian Ocean regions, Mon. Weather Rev., 115, 27-50, 1987.

Meehl, G. A.: The south Asian monsoon and the tropospheric biennial oscillation, J. Climate, 10, 1921-1943, 1997.

National Research Council (NRC): Committee on tropospheric ozone formation and measurement, Rethinking the ozone problem in urban and regional air pollution, National Academy Press, 1991.

National Science and Technology Department of Rural and Social Development Division: Air Pollution Control Strategies of Beijing, 82 pp., 2002.

Nicolas, A. M., Laura E. V., and Hipolito, C.: Analysis of NO, $\mathrm{NO}_{2}, \mathrm{O}_{3}$ and $\mathrm{NO}_{\mathrm{x}}$ concentrations measured at a green area of Buenos Aires City during wintertime, Atmos. Environ., 39(20), 3005-3068, 2005.

POPG: Ozone in the United Kingdom, Fourth Report of the UK photochemical oxidants review group, Department of the Environment, Transport and the Regions, London, UK, 1997.

Preisendorfer, R. W. and Mobley C. D.: Principal Component Analysis in Meteorology and Oceanography, Elsevier Science Publishing Company, New York, USA, 425 pp., 1988.
Seinfeld, J. H. and Pandis, S. N.: Atmospheric Chemistry and physics, From Air Pollution to Climate Changes, Wiley, New York, USA, 1326 pp., 1998.

State Environmental Protection Administration of China: China National Environmental Protection Standard: Automated Methods for Ambient Air Quality Monitoring, China Environmental Science Press, Beijing, 2006.

Stohl, A., Wotawa, G., Seibert, P., et al.: Interpolation errors in wind fields as a function of spatial and temporal resolution and their impact on different types of kinematic trajectories, J. Appl. Meteorol., 34, 2149-2165, 1995.

Stohl, A.: Computation, accuracy and applications of trajectories - a review and bibliography, Atmos. Environ., 32(6), 947-966, 1998.

Stunder, B.: An assessment of the quality of forecast trajectories, J. Appl. Meteorol., 35, 1319-1331, 1996.

Tsinghua University: Air quality safeguards Research of Beijing during the 29th Olympic games, 156 pp., 2007.

Ulke, A. G. and Mazzeo, N. A.: Climatological aspects of the daytime mixing height in Buenos Aires City, Aegentina, Atmos. Environ., 32(9), 1615-1622, 1998.

US Environmental Protection Agency: Air quality criteria for ozone and related photochemical oxidants, US EPA, National Center for Environmental Assessment, Research Triangle Park, NC, EPA/600/P-93/004F, Vol. I of III, p. 446, 1996.

Wakamatsu, S., Ohara, T., and Uno, I.: Recent trends in precursor concentrations and oxidant distributions in the Tokyo and Osaka areas, Atmos. Environ., 30, 715-721, 1996.

Wang, B., Wu, R., and Lau, K.-M.: Interannual Variability of the Asian Summer Monsoon: Contrasts between the Indian and the Western North PacificEast Asian Monsoons, J. Climate, 14, 4073-4090, 2001.

Wu, H. W. Y. and Chan, L. Y.: Surface ozone trends in Hong Kong in 1985-1995, Environ. Int., 26, 213-222, 2000.

Xu, X., Lin, W., Wang, T., et al.: Long-term trend of surface ozone at a regional background station in eastern China 1991-2006: enhanced variability, Atmos. Chem. Phys., 8, 2595-2607, 2008, http://www.atmos-chem-phys.net/8/2595/2008/.

Xiaoyan, T., Jinlong, L., and Zhenxing, D.: Photochemical Pollution in Lanzhou, China - A Case Study, J. Environ. Sci. (China), 1, 31-38, 1989.

Xiaoyan, T., Jinlong, L., and Danhua, C.: Summertime Photochemical Pollution in Beijing, Pure Appl. Chem., 67, 1465-1468, 1995.

Zhang, J., Miao, H., Ouyang, Z. Y., et al.: Ambient air quality trends and driving factor analysis since 1980s in Beijing, J. Environ. Sci.-China, 26(11), 1886-1892, 2006.

Zhang, Y. H., Shao, K. S., Tang, X. Y., et al.: The Study of Urban Photochemical Smog Pollution in China, Journal of Natural Science of Peking University, 34, 392-400, 1998. 